\title{
Research
}

\section{The differences in the quality of life of allergic rhinitis and non-symptomatic individuals}

\author{
Ayu Betty Hutagaol, Indri Adriztina \\ Department of Otorhinolaryngology-Head and Neck Surgery \\ Faculty of Medicine North Sumatera, Medan
}

\begin{abstract}
Background: Allergic rhinitis is a chronic inflammatory disorder of the nose that occurs as an IgEmediated reaction. Classical symptoms of allergic rhinitis are sneezing, nasal congestion, nasal itching and rhinorrhea. The effects of allergic rhinitis can have an impact on daily activities that affect the quality of life of sufferers. Purpose: To determine the differences between the quality of life of allergic rhinitis sufferers and non-symptomatic subjects in the Faculty of Medicine, University of North Sumatra batch 2017. Methods: This was an observational study with a cross-sectional design. The research sample was obtained by total sampling technique and used two questionnaires, Score for Allergic Rhinitis (SFAR) to assess allergic rhinitis, and 36-Item Short Form Health Survey (SF 36) to assess the quality of life of the research subjects, which were students of the Faculty of Medicine, University of North Sumatra, of the year 2017. Result: Among 213 students from the Faculty of Medicine, University of Sumatera Utara of the year 2017, there were 112 allergic rhinitis sufferers and 101 non-symptomatic students. The median quality of life score for allergic rhinitis sufferers was 74 , while the median score of quality of life for non-symptomatic students was 78. Using Man Whitney test, the result obtained $\mathrm{p}$ value $<0.05$ $(\mathrm{p}=0.044)$. Conclusion: There was a significant difference between the quality of life of students with allergic rhinitis and non-symptomatic individuals.
\end{abstract}

Keywords: allergic rhinitis, quality of life, SFAR, SF-36

\section{ABSTRAK}

Latar belakang: Rinitis alergi merupakan inflamasi yang terjadi pada hidung akibat adanya reaksi alergi yang diperantarai oleh IgE. Gejala rinitis alergi berupa bersin-bersin, hidung tersumbat, serta hidung gatal dan rinore. Gejala rinitis alergi dapat berdampak pada aktivitas sehari-hari sehingga mempengaruhi kualitas hidup penderitanya. Tujuan: Mengetahui perbedaan kualitas hidup penderita dan bukan penderita rinitis alergi pada mahasiswa Fakultas Kedokteran Universitas Sumatera Utara, angkatan 2017. Metode: Penelitian ini merupakan jenis penelitian analitik observasional dengan rancangan cross-sectional. Sampel penelitian ditentukan dengan teknik total sampling dan menggunakan dua buah kuesioner yaitu Score for Allergic Rhinitis (SFAR) untuk menilai rinitis alergi dan 36-Item Short Form Health Survey (SF-36) untuk menilai kualitas hidup. Subjek penelitian adalah mahasiswa Fakultas Kedokteran Universitas Sumatera Utara angkatan 2017. Hasil: Dari 213 mahasiswa Fakultas Kedokteran Universitas Sumatera Utara angkatan 2017, didapati 112 penderita rinitis alergi dan 101 bukan penderita rinitis alergi. Skor median kualitas hidup penderita rinitis alergi adalah 74 sedangkan skor median kualitas hidup mahasiswa bukan penderita rinitis alergi adalah 78. Dengan uji Man Whitney diperoleh hasil $p$ value $<0,05(p=0,044)$. Kesimpulan: Penelitian ini menunjukkan adanya perbedaan signifikan antara kualitas hidup penderita rinitis alergi dan bukan penderita rinitis alergi.

Kata kunci: rinitis alergi, kualitas hidup, SFAR, SF 36

Correspondence address: Ayu Betty Hutagaol. Department of Otorhinolaryngology-Head and Neck Surgery, Faculty of Medicine North Sumatera, Medan. E-mail: ayubhutagaol@gmail.com. 


\section{INTRODUCTION}

Allergic rhinitis is type 1 hypersensitivity reactions of the nasal mucosa causing characteristic symptoms. The main symptoms of allergic rhinitis are nasal congestion, rhinorrhea, sneezing and nasal itching. The most common and disturbing symptom in adults and children is nasal congestion. ${ }^{1,2}$

Allergic rhinitis is a worldwide healthrelated problem affecting $10-20 \%$ of the population and is the most common noncommunicable chronic disorder. According to a survey report conducted by WHO, as many as 400 million people in the world suffer from allergic rhinitis and it is estimated that the incidence rate will always increase..$^{3-5}$

The classification of allergic rhinitis according to Allergic Rhinitis and Its Impact on Asthma (ARIA) consensus, based on the duration of symptoms is intermittent (sometimes) and persistent (persistent), and based on the level of severity, namely mild and moderate-severe. ${ }^{6}$

Allergic rhinitis can significantly affect the quality of life of the sufferers. ${ }^{7,8}$ This ailment causes absence from school and work and decreasing productivity, in addition to economic burdens due to care costs. Nasal obstruction with sleep disorders will have an impact on causing psychological distress in the individual. Many epidemiological studies show a link between allergic and psychological factors. ${ }^{9}$ Studies show allergic rhinitis patients suffer from anxiety, depression, hypochondriasis, somatization, psychic asthenia and social introversion. There is a link between IgE levels and psychological disorders. Depression and other psychological disorders are associated with higher IgE levels. ${ }^{10}$

It was proven that allergic rhinitis patients had a significantly lower quality of health. Almost twice as many allergic rhinitis patients rated their health as poor $(27 \%)$ compared to individuals without nasal allergy $(15 \%) .{ }^{5,11}$
The increasing incidence of allergic rhinitis from year to year, and the high prevalence of allergic rhinitis among the students inspired the authors to observe the quality of life of allergic rhinitis sufferers and non-rhinitis persons. This study was conducted to determine the differences in the quality of life for allergic rhinitis sufferers and non-symptomatic subjects.

\section{METHOD}

This was an analytical observational study with cross sectional approach. The population were all students of the Faculty of Medicine, University of North Sumatra, batch 2017. Data collection was carried out by distributing online questionnaires to the research sample. This research was conducted in the period July-December 2020.

Samples were obtained by total sampling, taking all data samples were chosen based on inclusion and exclusion criteria. The inclusion criteria were students who were willing to fill out the SFAR and SF-36 questionnaires. The exclusion criteria were students who did not fill out the questionnaire completely.

This study used the SFAR (Score for Allergic Rhinitis) questionnaire to assess allergic rhinitis and the SF-36 (36-Item Short Form Health Survey) questionnaire to assess the quality of life. Value of the SFAR questionnaire is $\geq 7$ which can optimally differentiate between individuals with allergic rhinitis and those who are not sufferers of allergic symptoms. ${ }^{12}$

The SF-36 is a very popular instrument for evaluating health-related quality of life. The SF-36 questionnaire consists of 2 component concepts, namely the Physical Component Score and the Mental Component Score. ${ }^{13}$ A bigger score indicates a better quality of life.

The data obtained from the research will be entered into a computer using the SPSS 
application. The obtained data were then evaluated with Kolmogorov Smirnov test to find out the distribution.

Parametric analysis test independent- $t$ test if the data was normally distributed, or used the Whitney test if the data was not normally distributed.

This study had received approval from the Research Ethics Commission of the Faculty of Medicine, University of North Sumatra.

\section{RESULT}

This study was performed on 213 students, who had complied with the inclusion and exclusion criteria.

The general characteristic of research subjects was presented in Table 1, showed respondent's distribution based on age, gender, history of other atopy diseases and family history of atopy.

Age distribution showed that the highest allergic rhinitis (RA) sufferer's age was 21 years as many as 111 patients (52\%) where the majority was female 134 subjects $(63 \%)$. Subjects with history of other atopy diseases was $19(8.9 \%)$ and subject with family history of atopy was $74(34.7 \%)$.

Table 2 showed the quality of life for AR and non-RA individuals. Kolmogorov Smirnov test was used to calculate the data distribution, it showed abnormal distribution.

It was found that the median quality of life of patients with AR was 74 with a median domain of quality of life for physical components of 82 and a mental component of 74 . While the quality of life for nonsymptomatic sufferers was 78 , the median domain of the quality of life for the physical component was 85 and the mental component was 78. Score 0 (bad) to 100 (perfect).

After the data normality test was carried out using the Whitney test, it was found that the $p$ value was $<0.05(p=0.044)$ so that it could be concluded that there was a difference between the quality of life of people with RA and the quality of life of non-symptomatic individuals.

Tabel 1. Respondent's distribution based on age, gender, history of other atopy diseases and family history of atopy

\begin{tabular}{|c|c|c|c|c|}
\hline Variable & Rhinitis allergy sufferers & Non- & symptomatic & $\begin{array}{r}\text { Percentage } \\
(\%)\end{array}$ \\
\hline \multicolumn{5}{|l|}{ Age } \\
\hline 19 & 2 & & 4 & 3 \\
\hline 20 & 38 & & 25 & 30 \\
\hline 21 & 54 & & 57 & 52 \\
\hline 22 & 13 & & 13 & 13 \\
\hline 23 & 5 & & 0 & 2 \\
\hline \multicolumn{5}{|l|}{ Gender } \\
\hline Male & 38 & & 41 & 37.1 \\
\hline Female & 74 & & 60 & 62.9 \\
\hline \multicolumn{5}{|c|}{$\begin{array}{l}\text { History of other atopy dis- } \\
\text { eases }\end{array}$} \\
\hline Present & 17 & & 2 & $8.9 \%$ \\
\hline None & 95 & & 99 & $91.1 \%$ \\
\hline \multicolumn{5}{|c|}{ Family history of atopy } \\
\hline Present & 62 & & 12 & $34.7 \%$ \\
\hline None & 50 & & 89 & $65.2 \%$ \\
\hline
\end{tabular}


The differences in the quality of life

Table 2. Quality of life of AR sufferers and non-symptomatic.

\begin{tabular}{lccc}
\hline \multicolumn{1}{c}{ Components of quality of life } & RA sufferers & Non-symptomatic & p value \\
\cline { 2 - 3 } & $\begin{array}{c}\text { Median } \\
\text { (Minimum-Maximum) }\end{array}$ & $\begin{array}{c}\text { Median } \\
\text { (Minimum-Maximum) }\end{array}$ \\
\hline Physical component & $100(25-100)$ & $100(15-100)$ & 0.445 \\
Physical Functioning (PF) & $100(0-100)$ & $100(0-100)$ & 0.040 \\
Physical Role (RP) & $90(10-100)$ & $90(13-100)$ & 0.418 \\
Bodily Pain (BP) & $58(25-92)$ & $58(25-79)$ & 0.046 \\
General Health (GH) & $\mathbf{8 2 ( 2 5 - 9 8 )}$ & $\mathbf{8 5}(\mathbf{1 3 - 9 5})$ & $\mathbf{0 , 2 4 1}$ \\
\hline Subtotal & & $55(0-100)$ & 0.161 \\
\hline Mental Component & $52.5(15-92)$ & $75(13-100)$ & 0.199 \\
Vitality (VT) & $75(0-100)$ & $100(0-100)$ & 0.200 \\
Social Functioning (SF) & $100(0-100)$ & $68(4-100)$ & 0.540 \\
Emotional Role $(\mathrm{RE})$ & $56(8-100)$ & $\mathbf{6 8}(\mathbf{4 - 1 0 0 )}$ & $\mathbf{0 . 0 5 4}$ \\
Mental Health $(\mathrm{MH})$ & $\mathbf{5 6 ( 8 - 1 0 0 )}$ & $\mathbf{7 8 ( 9 - 9 5 )}$ & $\mathbf{0 . 0 4 4}$ \\
\hline Subtotal & $\mathbf{7 4 ( 2 6 - 9 4 )}$ & & \\
\hline Total quality of life & & & \\
\hline
\end{tabular}

\section{DISCUSSION}

In this study, it was found that patients with allergic rhinitis were dominated by women consisting of 74 people $(55.2 \%)$. Research results showed allergic rhinitis was more common in adult female than male. ${ }^{4}$ There was evidence of the involvement of the hormones estrogen and progesterone in women in allergic rhinitis. The hormones estrogen and progesterone in women have an inflammatory effect, whereas testosterone in men has an anti-inflammatory effect. ${ }^{2,5}$

Based on the age distribution, the highest number of allergic rhinitis was at the age of 21 years as many as $111(52 \%)$. This is in accordance with the theory stated that allergic rhinitis sufferers were in adulthood. The results of other studies were in line, reporting $80 \%$ of allergic rhinitis was developed by the age of $20 .^{2,4,14}$

In our study, the highest number of other atopy diseases was in 19 subjects, which was dominated by asthma, supported by studies that report that $30 \%$ to $90 \%$ of patients with asthma have concomitant rhinitis. The same thing is also explained that the relationship between asthma and rhinitis in adults has been recognized for decades, which shows that the majority of 1000 asthma sufferers also suffer from rhinitis. ${ }^{15}$

Allergic sensitivity to allergens is a major cause of an important risk factor in the relationship between rhinitis and asthma. A positive correlation was found between duration and severity of asthma and allergic rhinitis. ${ }^{10,16}$

Our study found the distribution of family history of atopy was 74 subjects. Research which states that a child who comes from a family with a history of allergic disease will be at risk of experiencing allergic disease two to three times higher than those who do not have a history of allergic disease in their family. ${ }^{7,814}$

A study conducted upon more than 3000 students at Japanese universities also revealed a positive relationship between family history and allergic rhinitis. ${ }^{8,14,17}$

Based on the analysis results, our study found that the difference between the quality of life scores of students with $p$ value $<0.05$ $(p=0.044)$. In medicine the formulation of 
the definition of quality of life is a health condition by considering the physical state, mental state, social situation and body sensations. $^{18}$

Research related to SF-36, statistically there is a difference in quality of life between the allergic rhinitis group and the control group. Both physical and mental health status, which adversely affect sufferers. A 2015 study conducted on college students with a $58.5 \%$ prevalence of allergic rhinitis also reported lower quality of life. ${ }^{19,20}$

The same thing is supported by studies conducted in Korea on adults who reported the impact of allergic rhinitis on the physical health of sufferers, which stated that the symptoms of allergic rhinitis had an adverse effect on sleep, daily activities, physical status, mental and social function. Allergic rhinitis sufferers also experienced fatigue, headaches, mood and sleep disorders, physical disturbances, mental problems, and cognitive dysfunction. ${ }^{10,21}$

In the mental health aspect, this is consistent with research that studies relationships in aspects of molecular biology, psychoneuroimmunology, and pharmacogenetics, reporting that the intranasal immune response can directly influence the biochemical response of the central nervous system, which can lead to psychological disorders. Psychological disturbances in allergic patients consequently increase and prolong the symptoms of allergic rhinitis. ${ }^{9}$

Symptoms that cause a decrease in quality of life in patients with allergic rhinitis are due to the pathophysiology of allergic rhinitis after being sensitized, namely $\operatorname{IgE}$ is synthesized and then attached to the target cell. The cytokines or chemokines that play a role are IL-3, IL-4, IL-5, IL-13, granulocyte-machrophage colony stimulating factor (GM-CSF), eotaxin and regulation on activation of normal $\mathrm{T}$ cells expressed and secreted (RANTES). Which then inhalation of the antigen activates mast cells and Th2 cells in the respiratory tract. This situation will stimulate the production of inflammatory mediators such as histamine and leukotrienes and cytokines such as IL-4 and IL-5.,22

Our study found there was a difference between the quality of life between students with allergic rhinitis and students who did not suffer from allergic rhinitis.

\section{REFERENCE}

1. Meltzer EO. Allergic Rhinitis. Burden of Illness, Quality of Life, Comorbidities, and Control. Immunology and Allergy Clinics of North America. 2016; 36(2), 235-48.

2. Kasim M, Buchori RM. Hubungan Rinosinusitis Kronik Dengan Rinitis Alergi. Jurnal Ilmiah Kesehatan Sandi Husada. 2020; 11(1), 271-7.

3. Öçal R, Muluk NB, Mullol J. Epidemiology of Allergic Rhinitis 33. All Around the Nose: Basic Science, Diseases and Surgical Management .2019; 297.

4. Nurjannah N. Faktor Risiko Rinitis Alergi Pada Pasien Rawat Jalan Di Poliklinik THTKL Rumah Sakit Umum Daerah Zainoel Abidin (RSUDZA) Banda Aceh Tahun 2011. Jurnal Kedokteran Syiah Kuala. 2011; 11(2), 60-5.

5. Wardhani M, Juwita RI, Purwoko M. Hubungan Antara Jenis Kelamin dan Riwayat Asma dengan Rinitis Alergi pada Pelajar SMP Muhammadiyah 3 Palembang. MED-ART. 2020; 2(1).

6. Brożek JL, Bousquet J, Agache I, Agarwal, A., Bachert C, Bosnic Anticevich S, Brignardello-Petersen R., Canonica G,W., Casale T, Chavannes N H, Correia de J, Schünemann HJ. Allergic Rhinitis and its Impact on Asthma (ARIA) guidelines 2016 revision. Journal of Allergy and Clinical Immunology.2017; 140(4), 950-8.

7. Kamel TM, Abdelhai RA, Mowafy MA, Reda AM, Hassan MD. The effect of patient education on health related quality of life among allergic rhinitis patients in cairo university outpateint clinics. International Journal Of Scientific \& Techonlogy Research. 2015; 4(02):96-100. 
8. Husni TR, TH. Perbandingan Kadar Immunoglobulin E Serum Pada Pasien Rinitis Alergi Dengan Faktor Risiko Genetik. Journal of Medical Science. 2020; 1(1), 49-53.

9. Tonelli LH, Katz M, Kovacsics CE, Gould TD, Joppy B, Hoshino A, Postolache TT. Allergic rhinitis induces anxiety-like behavior and altered social interaction in rodents. Brain, behavior, and immunity. 2009; 23(6), 784-93.

10. Venkateswarlu V, Reddy R, Ch H, Kumari V. Prevalence of Psychological Stress in Allergic Rhinitis Patients Attending a Tertiary Care Hospital-A Cross Sectional Study. 2017;

11. Meltzer EO. Allergic Rhinitis. Burden of Illness, Quality of Life, Comorbidities, and Control. Immunology and Allergy Clinics of North America. 2016; 36(2), 235-48.

12. Annesi-MaesanoI, Didier A, Klossek M, Chanal I, Moreau D, Bousquet J. The score for allergic rhinitis (SFAR): A simple and valid assessment method in population studies. Allergy: European Journal of Allergy and Clinical Immunology. 2002; 57(2), 107-14.

13. Cordier R, Brown T, Clemson L, Byles J. Evaluating the longitudinal item and category stability of the SF-36 full and summary scales 47 using rasch analysis. BioMed Research International. 2018;

14. Nurjannah N. Faktor Risiko Rinitis Alergi Pada Pasien Rawat Jalan Di Poliklinik THTKL Rumah Sakit Umum Daerah Zainoel Abidin (RSUDZA) Banda Aceh Tahun 2011. Jurnal Kedokteran Syiah Kuala. 2011; 11(2), 60-5.

15. Cingi C, Gevaert $P$, Mösges R, Rondon $C$, Hox V, Rudenko M, Fokkens WJ. Multimorbidities of allergic rhinitis in adults: European academy of allergy and clinical immunology task force report. Clinical and Translational Allergy. 2017; 7(1), 17.

16. Singh RK, Simalti AK. Coexistence of Allergic Rhinitis in Children Attending Paediatric Asthma Clinic. Journal of Nepal Paediatric Society .2019; 39(3), 142-6.

17. Nishijima H, Suzuki S, Kondo K., Yamasoba T, Yanagimoto S. Environmental factors associated with allergic rhinitis symptoms in Japanese university students: A cross- sectional study. Auris Nasus Larynx. 2018; 45(5), 1006-13.

18. Jarosz M, Syed S, Błachut M ,Brzoza, KB. Emotional distress and quality of life in allergic diseases. Wiad Lek. 2020; 73(2), 370-3.

19. Cingi CC, Muluk NB, Hancı D, Şahin E. Impacts of allergic rhinitis in social communication, quality of life and behaviours of the patients. J Allergy Disord Ther. 2015; 2(002).

20. Kef K, Güven S. The Prevalence of Allergic Rhinitis and Associated Risk Factors Among University Students in Anatolia. Journal of Asthma and Allergy.2020; 13, 589.

21. Shin JH, Roh D, Lee DH, Kim SW, Kim SW, Cho JH, Kim BY. Allergic rhinitis and rhinosinusitis synergistically compromise the mental health and health-related quality of life of Korean adults: A nationwide population-based survey. 2018; Plos one, 13(1), e0191115.

22. Surjanto E, Purnomo J. Mekanisme Seluler dalam Patogenesis Asma dan Rinitis ; 2018. 